\title{
Toxicity of 2,3,5,6-tetrachlorophenol to willow trees (Salix viminalis)
}

\section{Clausen, Lauge Peter Westergaard; Jensen, Christian Kjær; Trapp, Stefan}

Published in:

Human and Ecological Risk Assessment

Link to article, DOI:

10.1080/10807039.2017.1403280

Publication date:

2018

Document Version

Peer reviewed version

Link back to DTU Orbit

Citation (APA):

Clausen, L. P. W., Jensen, C. K., \& Trapp, S. (2018). Toxicity of 2,3,5,6-tetrachlorophenol to willow trees (Salix viminalis). Human and Ecological Risk Assessment, 24(4), 941-948.

https://doi.org/10.1080/10807039.2017.1403280

\section{General rights}

Copyright and moral rights for the publications made accessible in the public portal are retained by the authors and/or other copyright owners and it is a condition of accessing publications that users recognise and abide by the legal requirements associated with these rights.

- Users may download and print one copy of any publication from the public portal for the purpose of private study or research.

- You may not further distribute the material or use it for any profit-making activity or commercial gain

- You may freely distribute the URL identifying the publication in the public portal 


\section{Toxicity of 2,3,5,6-tetrachlorophenol to willow trees (Salix viminalis)}

\section{Lauge PW Clausen, Christian Kjær Jensen* and Stefan Trapp}

* Corresponding author: Ipwc@env.dtu.dk

Department of Environmental Engineering, Building 115, Technical University of Denmark, Kgs Lyngby, 2800, Denmark

\section{Abstract}

Chlorinated phenols have been intensively investigated from an eco-toxicological point of view, however almost nothing is known about toxicity of tetrachlorophenol (TeCP) to higher terrestrial plants. This paper applied the willow tree acute toxicity test by Trapp et al. (2000) and studied the toxicity of 2,3,5,6-TeCP to willows (S. viminalis) at neutral and acidic conditions (roughly $\mathrm{pH} 7$ and 4) with inhibition of transpiration as toxic endpoint. At neutral $\mathrm{pH}$ the $\mathrm{EC}_{50}$ was $>10 \mathrm{mg} / \mathrm{L}$ while the $\mathrm{EC}_{50}$ at acidic conditions was $0.32 \pm 0.17$ $\mathrm{mg} / \mathrm{L}$, clearly indicating that toxicity is exerted by the non-ionic chemical fraction. Standard tests running at neutral $\mathrm{pH}$ are therefore not capturing the full toxicity of weak acids and bases.

\section{Introduction}

Chlorinated phenols have been widely used as pesticides, disinfectants and wood preservation agents in the sawmill industry in both Europe and the United States of America (Kitunen et al., 1987; Rappe et al., 1978). The main components of the wood preservation agents used were tri-, tetra- and pentachlorophenol (Kitunen et al., 1987; 
Kitunen et al., 1984). The high polychlorinated phenols are classified as very toxic to aquatic organisms and some of them are suspected carcinogens, thus constituting a potential risk to human and environmental health (ECHA, 2017). Recent studies indicate that some of the higher chlorinated phenols may generate multi resistant organisms in the environment (Muller, 2015). Due to their wide industrial applications, the toxicity of chlorinated phenols has been intensively investigated (Aruoja et al., 2011; Hulzebos et al., 1993; Sharma et al., 1997; Shigeoka et al., 1988). However, to the knowledge of the authors, the only existing phytotoxicity studies available for tetrachlorophenol (TeCP) on terrestrial plants, are with 2,3,4,5-TeCP on soybean (Glycine max L.) and barley (Hordeum vulgare L.) (Pfleeger et al., 1991) and a study of 2,3,4,6-TeCP on radish (Raphanus sativus L.) and Sudan grass (Sorghum sudane) (Sund and Nomura, 1963), neither of them consider the effects of $\mathrm{pH}$. The chlorinated phenols are weak acids, i.e. non-ionic at low $\mathrm{pH}$. It is well-established that the uptake of ionized compounds is lower than for their corresponding non-ionic fraction, resulting in higher toxicity of non-ionized electrolytes (Clausen and Trapp 2017; Rendal et al. 2011; Sijm et al. 2007; Trapp 2004; Saarikoski and Viluksela 1982). The pKa of TeCP varies between 5 and 7 depending on the isomer (Schultz 1987; Schwarzenbach and Westall 1985; Lepri et al. 1980), meaning that both the ionized and the neutral fractions occur under natural environmental conditions ( $\mathrm{pH} 4-10$ ) (Franco et al. 2010). This study aims to assess the phytotoxicity of 2,3,5,6-tetrachlorophenol $(2,3,5,6-\mathrm{TeCP})$ to terrestrial plants at neutral $(\mathrm{pH} 7)$ and acidic (pH 4) conditions.

\section{Materials and methods}

\subsection{Experimental setup}

The willow tree acute toxicity test by Trapp et al. (2000) was used to derive the effective concentration exerting effects on $50 \%$ of the population (EC50) in a preliminary range 
finding experiment for 2,3,5,6-TeCP at $\mathrm{pH} 7$ and 4 (exact $\mathrm{pH}$-values are provided in Table 2) with a subsequent refined test at $\mathrm{pH} 4$. The nominal concentrations tested were $0,0.1,1$ and $10 \mathrm{mg} \mathrm{TeCP} / \mathrm{L}$ and $0,0.2,0.5$ and $1 \mathrm{mg} \mathrm{TeCP} / \mathrm{L}$ for the range finding tests and the refined test, respectively. Aqueous concentrations at test termination were not measured. The aqueous solubility of 2,3,5,6-TeCP is reportedly $0.1 \mathrm{~g} / \mathrm{L}$ at $25^{\circ} \mathrm{C}$ (Ma et al., 1993) and $0.05 \mathrm{~g} / \mathrm{L}$ at $20^{\circ} \mathrm{C}$ (Albanis et al., 1998), with an estimated vapour pressure of $0.02 \mathrm{~Pa}$ (HSDB database by Toxnet). Using these data to calculate a dimensionless partitioning coefficient between air and water gives $2.2^{*} 10^{-5}$, which corresponds well to the Henry's law constant of $3.5 * 10^{-2} \mathrm{~Pa}^{*} \mathrm{~m}^{3 *} \mathrm{~mol}^{-1}$, estimated by a QSAR by Meylan and Howard (1991). Based on this, volatilization from water is expected to be negligible. 40 $\mathrm{cm}$ willow cuttings of Salix viminalis (S. viminalis) were pre-grown in a bucket of tap water at room temperature. When the cuttings sprouted and the leafy branches reached a length of approximately $30 \mathrm{~cm}$ the willows were transferred to $0.5 \mathrm{~L}$ Erlenmeyer flasks, wrapped in aluminum foil and filled with $400 \mathrm{~mL}$ modified ISO 8692 nutrient solution. All flasks were sealed by aluminum foil and parafilm to avoid direct evaporation. The two $\mathrm{pH}$-levels used were controlled by changing the nitrogen source of the nutrient solution from nitrate to ammonium and omitting the sodium bicarbonate buffer, as proposed by Mikes and Trapp (2010). The nutritional composition of the nutrient solution is presented in Table 1. The trees were fixed above the water surface so that only roots were in contact with the test solution to avoid adsorption to the submerged stem. After three days of adaptation the nutrient solution was exchanged by 2,3,5,6-TeCP-spiked nutrient solution. The temperature and humidity were approximately $15 \pm 3 \mathrm{oC}$ and $55 \pm 10 \%$, respectively. Toxicity was measured, at approximately $0,24,48$ and $72 \mathrm{~h}$ and $144 \mathrm{~h}$ for the preliminary tests and at 0,24 and 48 for the refined test. Effects on transpiration occur fast (within two days) why the refined test was terminated after $48 \mathrm{~h}$. This also minimizes the risk of diseases and pests. Toxicity was measured as decrease in transpiration (weight loss of the plant-flask-system) of the individual trees compared to the control trees and expressed as normalized relative transpiration (NRT\%): 
$N R T(C, t)(\%)=\frac{\frac{1}{n} \sum_{i=1}^{n} T_{i}(C, t) / T_{i}(C, 0)}{\frac{1}{m} \sum_{j=1}^{m} T_{j}(0, t) / T_{j}(0,0)} \times 100 \quad$ (Trapp et al. 2000)

where $\mathrm{C}$ is TeCP concentration in solution $(\mathrm{mg} / \mathrm{L}), \mathrm{t}$ is the time period $(\mathrm{h}), \mathrm{T}$ is the absolute transpiration $(\mathrm{g} / \mathrm{h})$, and the indices, $\mathrm{i}$ and $\mathrm{j}$, indicate the replicates of test plants and control plants, respectively $(n=m=5)$.

Table 1 Composition of the ISO 8692 nutrient solution.

\begin{tabular}{l|c:l:c}
\hline Macronutrient & Conc. (mg/L) & Micronutrients & Conc. ( $\mu \mathrm{g} / \mathrm{L})$ \\
\hline $\mathrm{NaNO}_{3}{ }^{*}$ & 240 & $\mathrm{FeCl}_{3} \cdot 6 \mathrm{H}_{2} \mathrm{O}$ & 100 \\
$\mathrm{NH}_{4} \mathrm{Cl}^{*}$ & 53 & $\mathrm{Na}_{2} \mathrm{EDTA} \cdot 2 \mathrm{H}_{2} \mathrm{O}$ & 200 \\
$\mathrm{MgCl}_{2} \cdot 6 \mathrm{H}_{2} \mathrm{O}$ & 12 & $\mathrm{H}_{3} \mathrm{BO}_{3}$ & 185 \\
$\mathrm{CaCl}_{2} \cdot 2 \mathrm{H}_{2} \mathrm{O}$ & 18 & $\mathrm{MnCl}_{2} \cdot 4 \mathrm{H}_{2} \mathrm{O}$ & 415 \\
$\mathrm{MgSO}_{4} \cdot 7 \mathrm{H}_{2} \mathrm{O}$ & 15 & $\mathrm{ZnCl}_{2}$ & 3 \\
$\mathrm{KH}_{2} \mathrm{PO}_{4}$ & 32 & $\mathrm{CoCl}_{2} \cdot 6 \mathrm{H}_{2} \mathrm{O}$ & 1.5 \\
$\mathrm{NaHCO}_{3}{ }^{*}$ & 150 & $\mathrm{CuCl}_{2} \cdot 2 \mathrm{H}_{2} \mathrm{O}$ & 0.01 \\
& & $\mathrm{Na}_{2} \mathrm{MoO}_{4} \cdot 2 \mathrm{H}_{2} \mathrm{O}$ & 7 \\
\hline
\end{tabular}

EDTA: ethylene-diamine-tetra- acetic acid

* $\mathrm{NH}_{4} \mathrm{Cl}$ substituted $\mathrm{NaNO}_{3}$ and the buffer $\mathrm{NaHCO}_{3}$ when testing at $\mathrm{pH} 4$.

Table is modified from Mikes and Trapp (2010)

\subsection{Statistics and statistical software}

One-way ANOVAs were performed to test for statistical differences of the mean of the treatment groups, with subsequent Bonferroni post hoc test. For data with unequal variances a Kruskal-Wallis test was performed followed by Dunn's post hoc test. The ANOVAs were performed in GraphPad Prism with an error probability, $\alpha$, of 0.05 . For generation of the dose-response curve the method described by Christensen et al. (2009), assuming a logarithmic-normal distribution of data and using a logit transformation, was applied. 


\section{Results and discussion}

The toxicity of 2,3,5,6-TeCP to willow trees at $\mathrm{pH} 7$ and 4 was tested. Figure 1 presents the $\mathrm{NRT}(\%)$ and the average transpiration $(\mathrm{g} / \mathrm{d})$ for the range finding test at $\mathrm{pH} 7$ (Figure $1 \mathrm{~A}, \mathrm{~B}$ ), the corresponding test at $\mathrm{pH} 4$ (Figure 1C,D) and the final experiment at $\mathrm{pH} 4$ with refined concentration range (Figure 1E,F). At neutral $\mathrm{pH}$ the effect of 2,3,5,6-TeCP on transpiration of the willows is weak and statistically insignificant $(\mathrm{P}>0.05)$ even at the highest tested concentration $(10 \mathrm{mg} / \mathrm{L})$. In comparison, the toxicity exerted at acidic conditions is much higher. Here the two highest concentrations (10 mg/L and $1 \mathrm{mg} / \mathrm{L}$ ) reduced the NRT(\%) and the actual transpiration rates more than $75 \%$ within $48 \mathrm{~h}$ (Figure 1C). In both cases the inhibition was statistically significant $(\mathrm{P}<0.05)$. In the preliminary range finding test, at nominal $\mathrm{pH}$ of 4 , concentrations of $0.1 \mathrm{mg} / \mathrm{L}$ and lower did not exert statistically significant toxicity to the willows $(\mathrm{P}>0.05)$. These findings are also supported by the growth of the willows (Table 2), which indicates that the trees exposed to 1 and $10 \mathrm{mg} / \mathrm{L}$ at low $\mathrm{pH}$ were wilting (negative growth). The refined toxicity study at $\mathrm{pH} 4$ indicates a clear dose response relationship as evident from Figure 1E-F and Figure 2. In the refined study, the highest tested concentration of $1 \mathrm{mg} / \mathrm{L}$ reduced the NRT(\%) and the actual transpiration rate by more than $80 \%$ within $48 \mathrm{~h}$ of exposure which was statistically significant $(\mathrm{P}<0.05)$. 

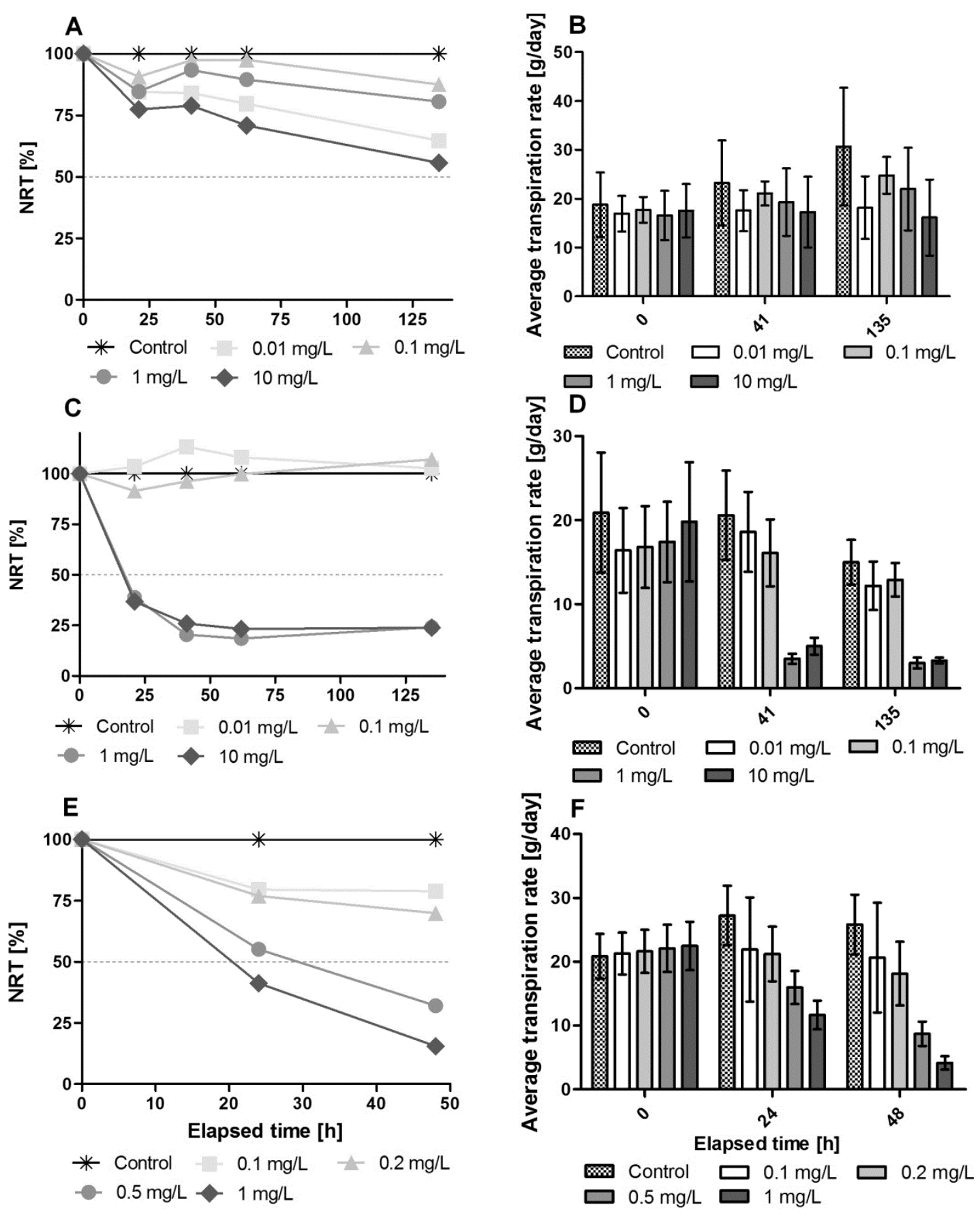

Figure 1. Visual representations of the NRT (\%) (A,C,E) and average transpiration rate (g/day) (B,D,F) for the range finding experiment at high $\mathrm{pH}(\mathrm{A}$ and $\mathrm{B})$, the range finding experiment at low $\mathrm{pH}(\mathrm{C}$ and $\mathrm{D})$ and the final experiment with low $\mathrm{pH}$ (E and F). The error bars in the column plots denote standard deviations among replicates. 
Table $2 \mathrm{pH}$ and weight change of the treatments for range finding tests and the refined test. The bracketed numbers denotes the standard errors.

\begin{tabular}{l|c:c:c}
\hline & $\mathbf{p H}$, initial & $\mathbf{p H}$, final & $\begin{array}{c}\text { Weight change } \\
(\%)\end{array}$ \\
\hline Range-finding, neutral pH & & & \\
Controls & $8.1(0.1)$ & $6.7(0.1)$ & $7.4(4.4)$ \\
$0.01 \mathrm{mg} / \mathrm{L}$ & $8.0(0.1)$ & $6.7(0.1)$ & $5.4(0.8)$ \\
$0.1 \mathrm{mg} / \mathrm{L}$ & $8.2(0.1)$ & $6.7(0.1)$ & $4.8(6.7)$ \\
$1 \mathrm{mg} / \mathrm{L}$ & $8.2(0.02)$ & $6.9(0.1)$ & $6.6(1.0)$ \\
$10 \mathrm{mg} / \mathrm{L}$ & $8.0(0.1)$ & $7.0(0.1)$ & $0.8(1.8)$ \\
\hline Range-finding, low pH & & & \\
Controls & $5.1(0.2)$ & $3.7(0.1)$ & $0.9(3.1)$ \\
$0.01 \mathrm{mg} / \mathrm{L}$ & $5.7(0.3)$ & $3.7(0.1)$ & $2.1(1.4)$ \\
$0.1 \mathrm{mg} / \mathrm{L}$ & $5.8(0.4)$ & $3.6(0.1)$ & $2.3(1.5)$ \\
$1 \mathrm{mg} / \mathrm{L}$ & $5.5(0.4)$ & $4.7(0.2)$ & $-10.3(1.4)$ \\
$10 \mathrm{mg} / \mathrm{L}$ & $5.2(0.3)$ & $5.1(0.1)$ & $-12.7(3.0)$ \\
\hline Refined, low pH & & & \\
Controls & $5.1(0.1)$ & $3.5(0.03)$ & $\mathrm{nm}$ \\
$0.1 \mathrm{mg} / \mathrm{L}$ & $5.0(0.1)$ & $3.5(0.04)$ & $\mathrm{nm}$ \\
$0.2 \mathrm{mg} / \mathrm{L}$ & $5.1(0.1)$ & $3.5(0.04)$ & $\mathrm{nm}$ \\
$0.5 \mathrm{mg} / \mathrm{L}$ & $5.1(0.03)$ & $3.5(0.03)$ & $\mathrm{nm}$ \\
$1 \mathrm{mg} / \mathrm{L}$ & $5.0(0.04)$ & $4.7(0.2)$ & $\mathrm{nm}$ \\
\hline $\mathrm{nm}$ not measured & & &
\end{tabular}

Table 2 shows the measured initial and final $\mathrm{pH}$ of the test solutions of the three experimental setups (the range finding tests at neutral and acidic conditions and the refined test at acidic conditions). With nitrate as nitrogen source and sodium carbonate as buffer, initial $\mathrm{pH}$ is $8-8.2$, and the final $\mathrm{pH}$ is $6.8-7$, i.e. the solution is neutral. With ammonium as nitrogen source and unbuffered, the initial $\mathrm{pH}$ varies from 5-5.5. The final $\mathrm{pH}$ depends on the health of the trees and thus also on the dosage of TeCP. The limited transpiration at high test concentrations results in reduced uptake of nitrogen and, in the case of ammonium as nitrogen source, less protons excreted by the plants. Final $\mathrm{pH}$ ranges from 3.5-4.7 with the highest $\mathrm{pH}$ observed for the high exposure groups. The $\mathrm{pKa}$ of 2,3,5,6-TeCP is reported by Schultz (1987), Lepri et al. (1980) and Doedens (1965) to $5.14,5.44$ and 5.48, respectively, resulting in approximately $97-99 \%$ ionization at $\mathrm{pH} 7$ and approximately 3.2-6.8\% ionization at $\mathrm{pH} 4$, when calculated by the HendersonHasselbach equation. This is also confirmed by our results (Figure 1 and Table 2). The 
EC50 is $>10 \mathrm{mg} / \mathrm{L}$ at $\mathrm{pH} 7$ and $0.32 \pm 0.17 \mathrm{mg} / \mathrm{L}$ at $\mathrm{pH} 4$ (deviation is $95 \%$ confidence interval, Figure 2), clearly showing the increased uptake and thus toxicity of the nonionic species. In comparison, the EC50-values obtained by Pfleeger et al. (1991) for $2,3,4,5-\mathrm{TeCP}$ on soybean and barley were $1 \pm 0.2 \mathrm{mg} / \mathrm{L}$ and $7.6 \pm 1.3 \mathrm{mg} / \mathrm{L}$, respectively, (deviation reported are standard errors) in a hydroponic experiment. For 2,3,4,6-TeCP Sund and Nomura (1963) reports EC50-values of $16 \mathrm{mg} / \mathrm{L}$, and $67 \mathrm{mg} / \mathrm{L}$ for radish and sudan grass in a seed germination test on filter paper (no confidence intervals reported). The values are approximately one to two orders of magnitude higher than the EC50-value reported in this study for the non-ionized compound and is likely to be in the similar range for the ionized fraction. Neither Pfleeger et al. (1991) nor Sund and Nomura (1963) reported the corresponding $\mathrm{pH}$ values. Most likely, their results are valid for neutral $\mathrm{pH}$.

Environmental concentrations of $\mathrm{TeCP}$ and other chlorophenols are in general low (in the $\mu \mathrm{g} / \mathrm{kg}$ dry weight range) (Czaplicka, 2004) but in the proximity of industrial sites, e.g. wood preservation facilities, high concentrations have been observed (in the $\mathrm{mg} / \mathrm{kg}$ dry weight range) (Knuutinen et al., 1990). Environmental concentration of TeCP may thus, at some industrial sites, be problematic from a phytotoxicity perspective at acidic conditions. 


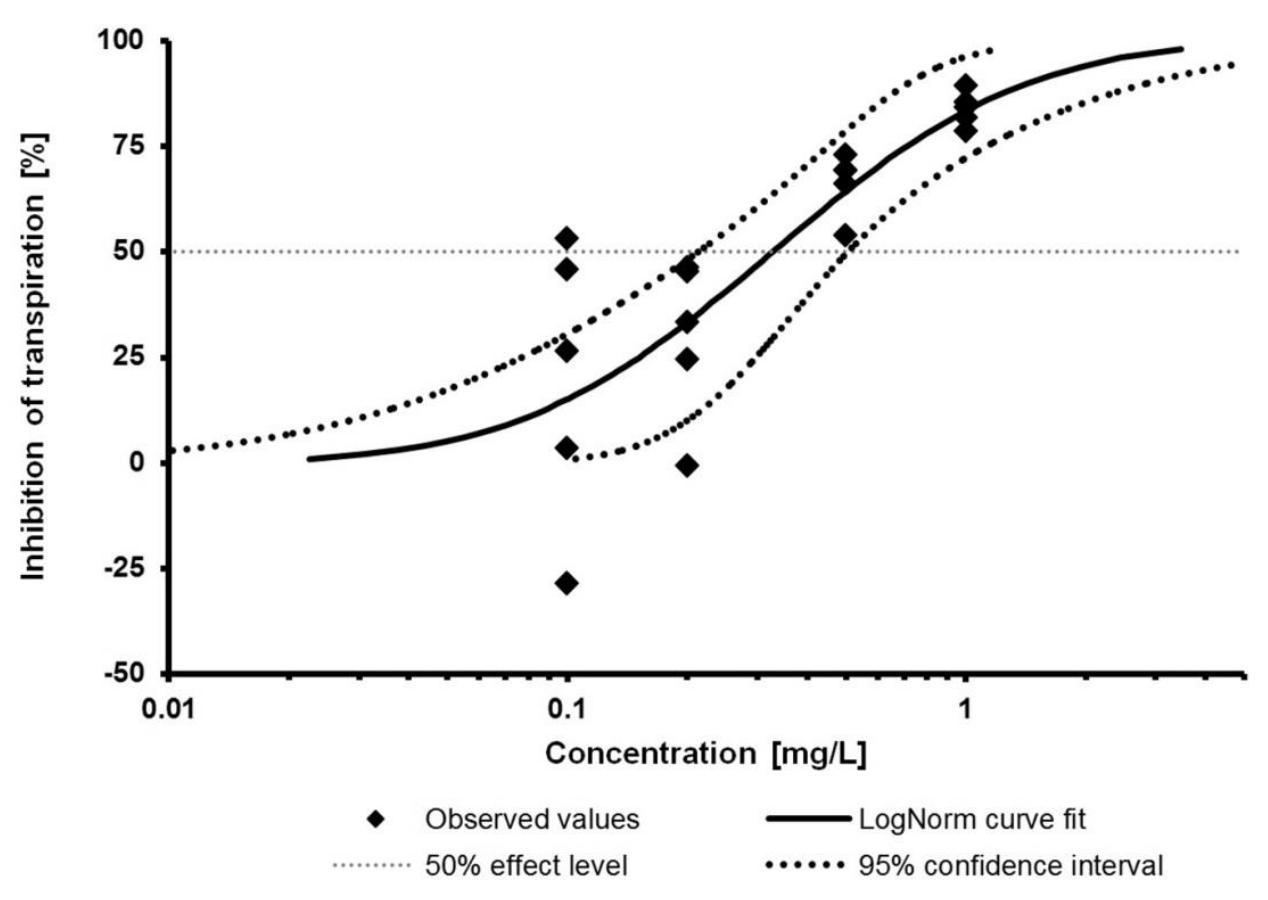

Figure 2. LogNorm fitted dose-response curve (bold black line) used to derive the $\mathrm{EC}_{50}$-value for the low $\mathrm{pH}$ experiment with refined exposure concentrations with corresponding 95\% confidence intervals (dotted lines).

As argued by e.g. Rendal et al. (2012), it has to be stressed that toxicity tests must be carried out at various $\mathrm{pH}$ regimes when assessing the risks of ionizing compounds. The necessity of such precaution is acknowledged in the REACH guidelines, stating that "it may be necessary to determine the toxicity of both anionic and cationic species" for compounds ionizing "to a significant extent" within pH 4-9 (ECHA 2016). Such precautions are not mentioned in the actual REACH regulation (ECHA 2006).

For the sake of plant health, standardized toxicity tests for terrestrial plants advice to use a pH between 6 and 7.5 in soil tests (ISO 2005; OECD 2006a; OECD 2006b; ASTM 2014). In this study the willow biomass increased by $0.9 \%$ at low $\mathrm{pH}$, while increasing by $7.4 \%$ at neutral $\mathrm{pH}$ (Table 2), indicating stress in the low $\mathrm{pH}$ regime. It must be noted that such stress can potentially cause elevated sensitivity of the willows towards the test substance, in which case the actual toxicity might be overestimated. On the other hand, the lower transpiration rate at low $\mathrm{pH}$ lead to lower exposure, which will affect the result 
in the opposite direction, i.e. the toxicity may be underestimated. Work remains in pursuit of standardized terrestrial plant tests suitable for low and high $\mathrm{pH}$ regimes.

\section{References}

Albanis, TA, Danis, TG, Kourgia MG. 1998. Adsorption-desorption studies of selected chlorophenols and herbicides and metal release on soil mixtures with fly ash. Environmental Technology 19: 25-34.

American Section of the International Association for Testing Materials (ASTM). 2014. Standard Guide for Conducting Terrestrial Plant Toxicity Tests. Vol. E1963-9. Link: https://compass.astm.org/EDIT/html_annot.cgi?E1963+09(2014) - accessed Sept. $6^{\text {th }}$, 2017.

Aruoja V, Sihtmäe M, Dubourguier HC, Kahru A. 2011. Toxicity of 58 substituted anilines and phenols to algae Pseudokirchneriella subcapitata and bacteria Vibrio fischeri: comparison with published data and QSARs. Chemosphere 84 (10): 13101320.

Christensen ER, Kusk KO, Nyholm N. 2009. Dose-response regressions for algal growth and similar continuous endpoints: calculation of effective concentrations. Environ Toxicol Chem 28 (4): 826-835.

Clausen LPW, Trapp S. 2017. Toxicity of 56 substances to trees. Environ Sci Pollut R 113.

Czaplicka M. 2004. Sources and transformations of chlorophenols in the natural environment. Sci Tot Environ 322 (1): 21-39. 
Doedens, JD. 1965. In Kirk-Othmer, Encyclopedia of Chemical Technology, 2nd ed.; Kirk, RE, Othmer, DF, Mark, HF, Stander, A, Eds.; Wiley: New York, 1965; Vol. 5, p 325 .

Hulzebos EM, Breemen DV, van Dis WA, Herbold HA, Hoekstra JA, Baerselman R, van Gestel CAM, Adema DMM, Henzen L. 1993. Phytotoxicity studies with Lactuca sativa in soil and nutrient solution. Environ Toxicol Chem 12 (6): 1079-1094.

ECHA (European Chemicals Agency). 2006. Regulation (EC) No 1907/2006 of the European Parliament and of the Council of 18 December 2006 concerning the Registration, Evaluation, Authorisation and Restriction of Chemicals (REACH). Link: http://eur-lex.europa.eu/legalcontent/EN/TXT/?qid=1504518529960\&uri=CELEX:32006R1907 - accessed Sept. $4^{\text {th }}, 2017$.

ECHA (European Chemicals Agency). 2016. Guidance on Information Requirements and Chemical Safety Assessment, Chapter R.7b: Endpoint specific guidance. Pages 68, 81, 82 and 143. Link:

https://echa.europa.eu/documents/10162/13632/information_requirements_r7b_en.pdf /1a551efc-bd6a-4d1f-b719-16e0d3a01919 - accessed Sept. $4^{\text {th }}, 2017$.

ECHA (European Chemicals Agency). 2017. Hazard classification \& labelling of pentachlorophenol. Link: https://echa.europa.eu/da/substance-information//substanceinfo/100.001.617 - accessed Aug. $4^{\text {th }}, 2017$.

Franco A, Ferranti A, Davidsen C, Trapp S. 2010. An unexpected challenge: ionizable compounds in the REACH chemical space. Int J Life Cycle Assess 15 (4): 321-325.

ISO (International Organization for Standardization). 2005. Test no. 22030: Soil quality Biological methods - Chronic toxicity in higher plants. Vol. 2005-2-1. Link: https://www.iso.org/standard/36065.html - accessed Sept. $6^{\text {th }}, 2017$. 
Kitunen VH, Valo RJ, Salkinoja-salonen MS. 1984. Analysis of chlorinated phenols, phenoxyphenols and dibenzofurans around wood preserving facilities. Int $\mathrm{J}$ Environ Anal Chem 20 (1-2): 13-28.

Kitunen VH, Valo RJ, Salkinoja-Salonen MS. 1987. Contamination of soil around woodpreserving facilities by polychlorinated aromatic compounds. Environ Sci Technol 21 (1): 96-101.

Knuutinen J, Palm H, Hakala H, Haimi J, Huhta V, Salminen J. 1990. Polychlorinated phenols and their metabolites in soil and earthworms of sawmill environment. Chemosphere 20 (6): 609-623.

Lepri L, Desideri PG, Heimler D. 1980. Reversed-phase and soap thin-layer chromatography of phenols. J Chromatogr 195 (3): 339-348.

Ma KC, Shiu WY, Mackay D. 1993. Aqueous Solubilities of Chlorinated Phenols at 25 ${ }^{\circ} \mathrm{C}$. J. Chem. Eng. Data 38: 364-366.

Meylan WM, Howard PH. 1991. Bond contribution method for estimating henry's law constants. Environ Toxicol Chem 10: 1283-93.

Mikes O, Trapp S. 2010. Acute toxicity of the Dissociating veterinary antibiotics trimethoprim to willow trees at varying $\mathrm{pH}$. Bull Environ Contam Toxicol 85: 556561.

Muller JF, Ghosh S, Ikuma K, Stevens AM, Love NG. 2015. Chlorinated phenol-induced physiological antibiotic resistance in Pseudomonas aeruginosa. FEMS Microbiol Lett $362(21)$.

OECD (Organisation for Economic Co-operation and Development) (2006a) Test guideline 208: Terrestrial plant test - Seedling emergence and seedling growth test. OECD guidelines for the testing of chemicals. Link: http://www.oecd- 
ilibrary.org/environment/test-no-208-terrestrial-plant-test-seedling-emergence-andseedling-growth-test_9789264070066-en - accessed Sept. $6^{\text {th }}, 2017$.

OECD (Organisation for Economic Co-operation and Development) (2006b) Test guideline 227: Terrestrial plant test - Vegetative vigour test. OECD guidelines for the testing of chemicals. Link: http://www.oecd-ilibrary.org/environment/test-no-227terrestrial-plant-test-vegetative-vigour-test_9789264067295-en - accessed Sept. $6^{\text {th }}$, 2017.

Pfleeger T, Mc Farlane C, Sherman R, Volk G. 1991. A short-term bioassay for whole plant toxicity. Plants for Toxicity Assessment: Second Volume, ASTM STP 1115: 355-364.

Rappe C, Garå A, Buser HR. 1978. Identification of polychlorinated dibenzofurans (PCDFs) in commercial chlorophenol formulations. Chemosphere 7 (12): 981-991.

Rendal C, Kusk KO, Trapp S. 2011. The effect of pH on the uptake and toxicity of the bivalent weak base chloroquine tested on Salix viminalis and Daphnia magna. Environ Toxicol Chem 30 (2): 354-359.

Rendal C, Trapp S, Kusk KO. 2012. Critical evaluation and further development of methods for testing ecotoxicity at multiple $\mathrm{pH}$ using Daphnia magna and Pseudokirchneriella subcapitata. Environ Toxicol Chem 31 (8): 1843-1852.

Saarikoski J, Viluksela M. 1982. Relation between physicochemical properties of phenols and their toxicity and accumulation in fish. Ecotoxicol Environ Saf 6 (6): 501-512.

Schultz TW. 1987. The use of the ionization constant (pKa) in selecting models of toxicity in phenols. Ecotoxicol Environ Saf 14 (2): 178-183.

Schwarzenbach RP. 1985. Sorption of hydrophobic trace organic compounds in groundwater systems. Wat Sci Tech 17: 39-55. 
Sharma HA, Barber JT, Ensley HE, Polito MA. 1997. A comparison of the toxicity and metabolism of phenol and chlorinated phenols by Lemna gibba, with special reference to 2,4,5-Trichlorophenol. Environ Toxicol Chem 16 (2): 346-350.

Shigeoka T, Sato Y, Takeda Y, Yoshida K, Yamauchi F. 1988. Acute toxicity of chlorophenols to green algae, Selenastrum capricornutum and Chlorella vulgaris, and quantitative structure-activity relationships. Environ Toxicol Chem 7 (10): 847-854.

Sijm DTHM, Rikken MGJ, Rorije E, Traas TP, McLachlan MS and Peijnenburg WJGM. 2007. Transport, accumulation and transformation processes. In: van Leeuwen CJ and Vermeire TG. Risk assessment of chemicals: An introduction. 2nd edition. Springer. Netherlands. 149-150.

Sund KA, Nomura N, 1963. Laboratory Evaluation of Several Herbicides, Weed Res 3 (1): 35-43.

Trapp S. 2004. Plant uptake and transport models for neutral and ionic chemicals. Environ Sci Pollut Res 11 (1): 33-39.

Trapp S, Zambrano KC, Kusk KO, Karlson U. 2000. A phytotoxicity test using transpiration of willows. Arch Environ Contam Toxicol 39 (2): 154-160. 